\title{
Chemical Characterization and Antiradical Properties of Pyroligneous Acid from a Preserved Bamboo, Guadua angustifolia Kunth
}

Juliana Peña Gomez ${ }^{1}$

https://orcid.org/0000-0003-4120-9487

Juan Pablo Arrubla Velez ${ }^{1 *}$

https://orcid.org/0000-0003-3572-4247

María Alejandra Pinzon ${ }^{1}$

https://orcid.org/0000-0003-4843-5364
Jorge Augusto Montoya Arango 2

https://orcid.org/0000-0003-3778-7727

Andrés Prieto Muriel ${ }^{2}$

https://orcid.org/0000-0002-2300-5010

1 Universidad Tecnológica de Pereira, Oleochemical Research Group, Risaralda, Colombia; ${ }^{2}$ Universidad Tecnológica de Pereira, Cleaner Production Research Group, Risaralda, Colombia.

Editors-in-Chief: Paulo Vitor Farago

Associate Editor: Jane Budel

Received: 2019.12.05; Accepted: 2020.12.18.

*Correspondence: juanpablo77@utp.edu.co; Tel.: +573127910059 (J.P.A.V.).

\section{HIGHLIGHTS}

- Chemical characterization of PA extracts has high content of phenolic compounds.

- PA extracts from G. angustifolia may be used in the pharmaceutical industry and agriculture.

- A total of 66 compounds with approximate match percentage $\geq 89 \%$ were identified.

- The PA extracts showed a high content of antioxidant properties.

Abstract: Pyroligneous acid (PA) was obtained by condensation of the vapors produced in the thermal decomposition of culms residues from Guadua angustifolia Kunth ( $G$. angustifolia) cultivated in Colombia, with and without previous preservation treatment with borax salts. Chemical characterization by GC-MS showed that PA extracts has high content of phenolic compounds. Mequinol, isocreosol, 4-ethylphenol, 4ethyl-2-methoxyphenol, 3,5-dimethoxy-4-hydroxytoluene and 2,6-dimethoxyphenol were the most abundant substances, identified. The total phenolic content (TPC) and DPPH free radical scavenging activity, were investigated. TPC showed a concentration of $1.959 \mathrm{mg} \mathrm{GA} \mathrm{g}^{-1} \pm 0.010$ and $3.844 \mathrm{mg} \mathrm{GA} \mathrm{g}^{-1} \pm 0.027$ to PAC and PAS samples. These samples also exhibited high DPPH activity of $70.975 \% \pm 0.921$ and, $16.667 \% \pm 0.298$, respectively. The chemical composition, TPC and DPPH results indicate that the PA extracts obtained from $G$. angustifolia may be used as a raw material in the food industry as natural preservative, in medicine as alternative to antibiotics and in agriculture as insect repellent and foliar fertilizer.

Keywords: Guadua angustifolia Kunth; pyroligneous acid; gas chromatography - mass spectrometry; antioxidant activity; wood vinegar. 


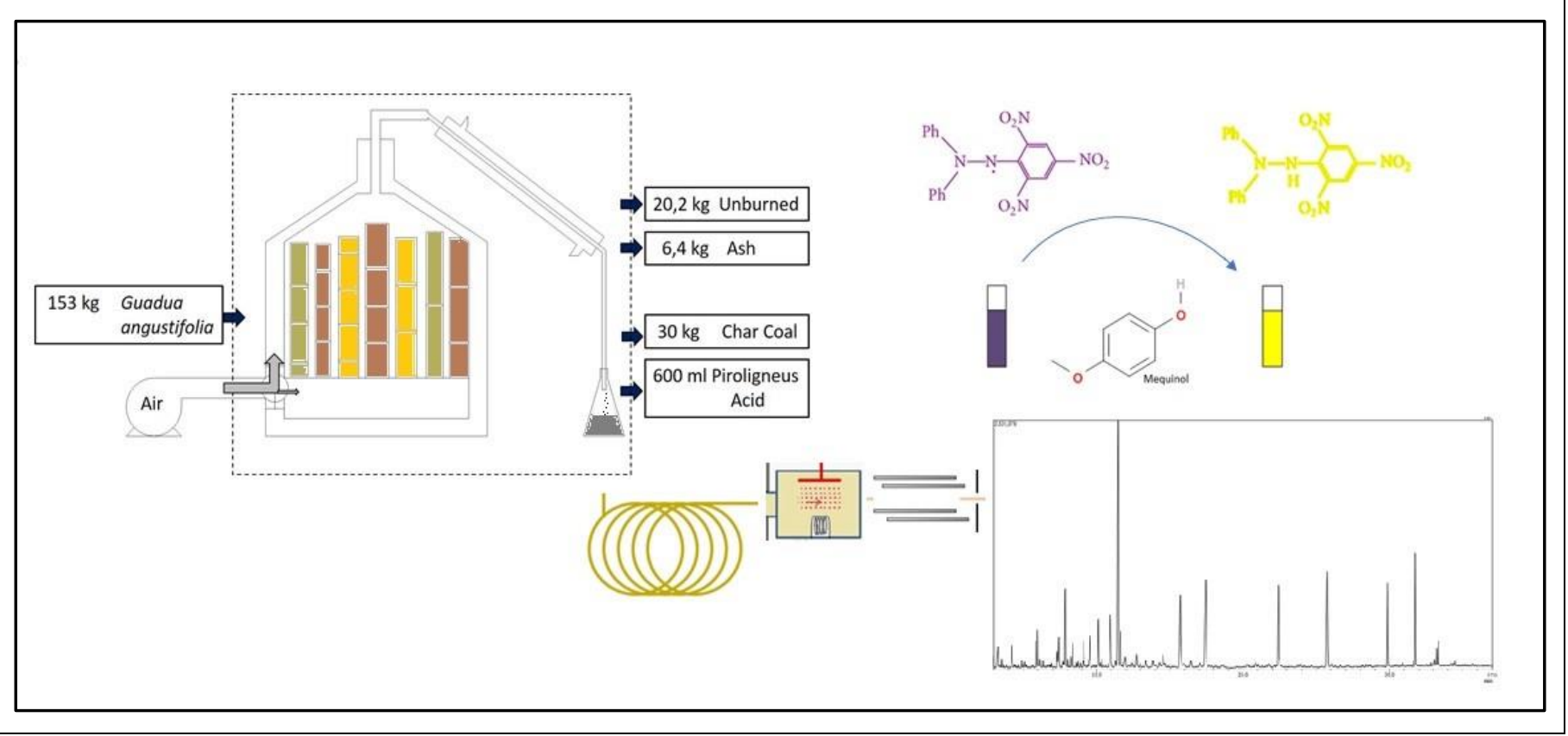

\section{INTRODUCTION}

There are approximately 1600 species of bamboo in the world, $64 \%$ of which are native to Southeastern Asia and 33\% of which grow in Latin America, with the others growing in Africa and Oceania [1]. As can be seen, bamboos are widely distributed in the tropical and subtropical regions of the world [2]. In Colombia, there is an area of 51000 ha of forest dominated by the botanical species of the grass subfamily Bambusoideae, called Guadua angustifolia Kunth (G. angustifolia). This type of bamboo has been part of a historical, cultural, economic, and environmental conservation tradition in the Colombian region, where coffee is grown. Currently, the total area comprises 28000 ha, of the total area, only planted are approximate 3000 ha [3]. Guadua bamboo forests fulfil critical ecological functions that benefit the coffee region's population [4].

Bamboo contains cellulose, hemicellulose, and lignin. The third most abundant constituent is lignin, an amorphous phenolic macromolecule responsible for the high structural resistance and the abundant composition of carbon atoms linked to $-\mathrm{OH}$ substituents in the bamboo. Lignin has great potential due of its important structural properties that is used in the biochemicals, biofuels and phenolic resins production, as well as in the polymer and pharmaceutical industries [5]. A considerable amount of the bamboo processed cannot be used for the manufacturing production and goes to the bioenergy production: charcoal is obtained by subjecting bamboo to a pyrolysis process, where combustion gases are emitted. This process involves a thermal decomposition of organic matter in the absence of oxygen. In the autothermic process, some oxygen is introduced to produce a partial combustion that adds heat to the process. The organic matter decomposes emitting gases, bio-oil, tar, PA and heavy residues that are used in very different ways [6].

Pyroligneous acid (PA) is acidic reddish-brown, and highly oxygenated organic aqueous liquid, byproduct from smoke condensate of pyrolysis process. PA consists of substances that belong to different classes of organic compounds, including aldehydes, ketones, alcohols, organic acids, esters, derivatives of furan and pyran, phenols, hydrocarbons, and nitrogen compounds; the main components are organic and phenolic acids [7]. With the presence of multiple compounds, PA has shown various potential benefits in agriculture as antimicrobial, soil improver, root growth promoter for plants, soil biostimulator, foliar fertilizer, and nematicide [8]. Also, it is used for sterilization, food additives and smoke flavoring [9].

The chemical composition of PA depends on the original wood species. The PA has been obtained from various lignocellulosic materials, including the mangrove plant (Rhizophora apiculata) [10]; PA obtained of oil palm tree (Elaeis guineesis) has the potential as an alternative ecofriendly source of natural antioxidant [11]; among others as walnut shells [12] and pineapple plant wastes [13]. In Latin America, some studies have investigated obtaining PA from wood residues. In Peru, Catacora-Pinazo and coauthors reported characterization of chemical components of PA obtained from Guadua sarcocarpa, Erythirina ulei and 
Cecropia sciadophylla, with agricultural purposes [14]. In Ecuador, Burbano-Salas and coauthors reported obtaining coal, tar and PA as a by-product of pruning waste from green areas used for agricultural activities [15]. In Colombia, Ocampo Gonzalez and coauthors characterized the chemical content of PA produced from residual biomass of conifers Cypress (Cupressus Lusitanica Mill) and Patula pine (Pinus patula) [16]; and Prías Barragán and coauthors identified the optimal variables for obtaining carbon and PA from G.angustifolia [17], specie used in this study.

Presently, there is no research to support the chemical composition of the PA obtained from $G$. angustifolia residues, nor the study of its antiradical properties. In the present investigation we present a complete characterization by GC-MS, showing that the studied PA can be used in the agricultural and food industry, due its high phenolic content and its antiradical properties determined by DPPH assay. In this way, the PA obtained as a by-product of the coal manufacture is a promissory raw material for industry in Colombia and worldwide.

\section{MATERIAL AND METHODS}

PA production

Samples of mature $G$. angustifolia with at least 4 years old from a sustainable management forest process in natural forest from enterprise GUADUASECOL S.A.S in department of Risaralda in the coffee region in Colombia was used to produce PA. $1 \mathrm{~m}$ long with diameter between 10 and $14 \mathrm{~cm}$ and wall depth between 7 and $15 \mathrm{~mm}$ from lower part of dried culms was subjected to a thermochemical process of pyrolysis [18], this process was carried out in $1 \mathrm{~m}^{3}$ batch reactor with self-heating arise temperatures around 250 to $280^{\circ} \mathrm{C}$ to produce charcoal, and during the process fumes were originated, which were condensed obtaining as a byproduct the PA. $372.5 \mathrm{~kg}$ of preserved Guadua and $153 \mathrm{~kg}$ of unpreserved Guadua were used as initial load in the combustion processes that lasted approximately 5 to 7 hours. (Figure 1 . Pyrolysis of $G$. angustifolia).

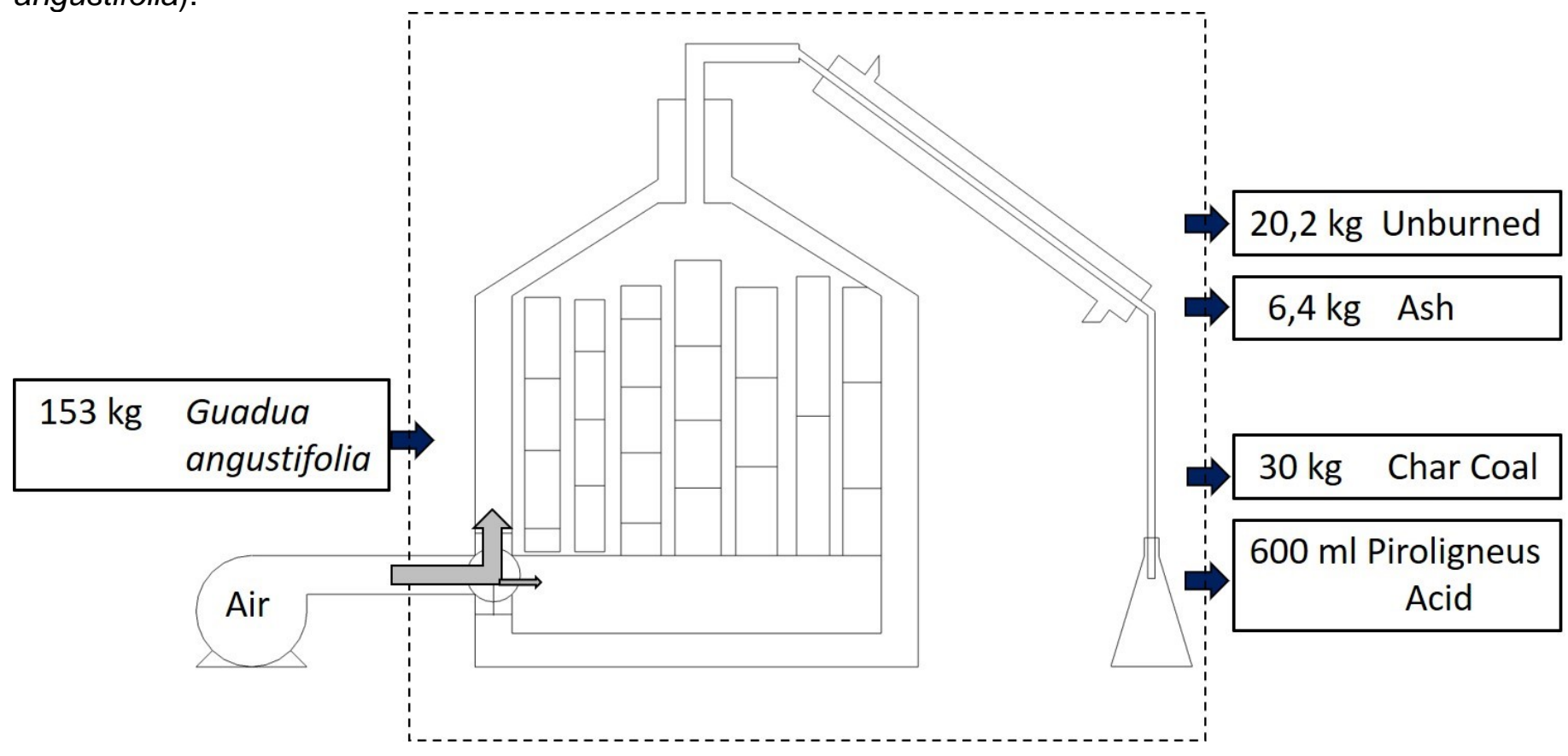

Figure 1. Pyrolysis of $G$. angustifolia.

The samples were obtained by pyrolysis from $G$. angustifolia with previous preservation treatment with borax salts, coded as PAC and from $G$. angustifolia without previous preservation treatment with borax salts, coded as PAS. The treatment was carried out by immersion in a hot solution of $2 \%$ Boric Acid and $2 \%$ Borax by at least $24 \mathrm{~h}$ and then they were dried by furnace in an Industrial processes [19]. All this treatment was made it in a private company located in Dosquebradas, Risaralda, Colombia.

Sample preparation for GC-MS analysis

Two different kinds of PA samples were used in this study: PAC and PAS. The PAs were filtered through Whatman No. 1 filter paper that it has particle retention of $11 \mu \mathrm{m}$ at $98 \%$ efficiency. The extraction of the 
interest analytes were carried out using the procedure described by Pimenta and coauthors (2018) with slight modifications [20]. An aliquot of $30 \mathrm{~mL}$ of each filtered sample was taken, and each aliquot was transferred to a separating funnel. Subsequently, $3 \mathrm{~mL}$ of hexane (95\% purity, J.T. Baker, Mexico) was added to the PAS aliquot. For the extraction of the compounds of interest from the PAC aliquot, it was necessary to add $20 \mathrm{~mL}$ of hexane. The two funnels were then vigorously shaken for $3 \mathrm{~min}$ and allowed to remain at rest for 15 hours. After liquid-liquid extraction, $0.5 \mu \mathrm{L}$ of the organic phase of each funnel was diluted using hexane in its respective vial to a volume of $1.5 \mathrm{~mL}$ and passed through a $0.2 \mu \mathrm{m}$ PTFE Membrane Disc Filters (Pall, USA). Chemical composition analysis by gas chromatography

The PAs chemical profiles were obtained in a gas chromatograph coupled to a Shimadzu QP-2020 mass spectrometer, equipped with a Shimadzu AOC-20i automatic injection port and a SH-Rxi-5Sil MS capillary column with $30 \mathrm{~m}$ length, $0.25 \mathrm{~mm}$ internal diameter and $0.25 \mu \mathrm{m}$ film thickness supplied by Shimadzu, USA. The chromatographic conditions used in the qualitative determination of the PA samples were the following: injection volume: $1 \mu \mathrm{L}$ with a 10:1 split ratio; injection mode: split, injector temperature: $280{ }^{\circ} \mathrm{C}$; helium (99.999\% purity, Colombia) was used as carrier gas with a constant flow rate of $1.00 \mathrm{~mL}$ min-1; purge flow: $2.0 \mathrm{~mL} \mathrm{~min}-1$; linear speed: $36.5 \mathrm{~cm} \mathrm{~s}-1$; pressure: $57.5 \mathrm{kPa}$. The oven temperature was set at $60^{\circ} \mathrm{C}$ for initial $3 \mathrm{~min}$, then increased to $90^{\circ} \mathrm{C}$ at a rate of $5^{\circ} \mathrm{C} \mathrm{min}-1$, held for $10 \mathrm{~min}$. Subsequently, the temperature was increased to $120^{\circ} \mathrm{C}$ at a rate of $10^{\circ} \mathrm{C} \mathrm{min}{ }^{-1}$, held for 5 min. Finally, the temperature was increased to $280^{\circ} \mathrm{C}$ at a rate of $10^{\circ} \mathrm{C} \mathrm{min}{ }^{-1}$, held for $5 \mathrm{~min}$; the run took $48 \mathrm{~min}$.

The mass spectrophotometer was operated using the following parameters: mass range of $\mathrm{m} / \mathrm{z} 40-500$, scan interval of $3 \mathrm{~s}$, and $70 \mathrm{eV}$ electron impact ionization mode. The identification of the compounds was based on a comparison of their mass spectra with the spectra of the NIST Mass Spectral Library, which also compared their retention indexes with those present in the literature. The contents of compounds were measured by their relative peak areas.

Determination of the total phenolic content (TPC) by the Folin-Ciocalteu assay

The TPC of PAC and PAS samples, were estimated using the procedure described by Loo and others (2007) with slight modifications [10]. First, $5 \mathrm{~mL}$ of $20 \%(\mathrm{w} / \mathrm{v})$ anhydrous sodium carbonate solution $(95 \%$ purity, Fisher Scientific, USA) was prepared using distilled water as a solvent. Then, $1 \mathrm{~mL}$ of distilled water, $50 \mu \mathrm{L}$ of sample, and $250 \mu \mathrm{L}$ of the Folin-Ciocalteu reagent (Merck KGaA, Germany) in a 1: 1 concentration ratio were mixed in a $5 \mathrm{~mL}$ flask. After one minute, $750 \mu \mathrm{L}$ of sodium carbonate solution was added, and the volume was completed using distilled water. The mixture was incubated at room temperature for $30 \mathrm{~min}$.

Absorbance measurements were recorded at a wavelength of $760 \mathrm{~nm} .50 \mu \mathrm{L}$ of sample and $750 \mu \mathrm{L}$ of sodium carbonate solution was taken as the blank and added to a $5 \mathrm{~mL}$ flask; the volume was completed using distilled water. A standard curve was constructed with gallic acid in a concentration range of 100 to 500 $\mathrm{mg} \mathrm{L}-1(\mathrm{y}=0.001 \mathrm{x}+0.0348, \mathrm{R} 2=0.9955)$ for the determination of $\mathrm{mg}$ of gallic acid equivalents per gram of sample (mg GA g-1). The values are presented as the mean of the data from samples analyzed in triplicate. $\mathrm{DPPH}$ free radical scavenging activity

The antioxidant activity of both PAC and PAS were determined according to the 1,1-diphenyl-2picrylhydrazyl (DPPH) method proposed by W. Brand-Williams and others [21], with some modifications. To $20 \mathrm{~mL}$ of $20 \mathrm{mg} \mathrm{L}-1 \mathrm{DPPH}$ (95\% purity, Alfa Aesar) in absolute methanol (99.9\% purity, JT Baker, Mexico) was prepared. A $2 \mathrm{~mL}$ of this solution was mixed with $30 \mu \mathrm{L}$ sample in an amber container. The mixture was shaken and allowed to stand for $30 \mathrm{~min}$ in a dark place at room temperature. Then, the absorbance was measured at a wavelength of $517 \mathrm{~nm}$ against methanol as a blank, using a UV-1700 spectrophotometer (Shimadzu, Kyoto, Japan). The average absorbance of each sample was adopted by conducting in triplicate, using equivalent cells.

Lower absorbance values for the reaction mixture indicated higher free radical scavenging activity. The percentage of DPPH discoloration of the samples was calculated according to the Equation 1:

$$
S C \%=\frac{A_{0}-A}{A_{0}} \times 100
$$

Where $A_{0}$ is the absorbance of the 1,1-diphenyl-2-picrylhydrazyl reagent, and $\mathrm{A}$ is the absorbance of the sample [22]. 


\section{Statistical analysis}

The experimental results are expressed as mean \pm standard deviation (S.D) of triplicate measurements. Microsoft excel 2010 was used to process the results.

\section{RESULTS AND DISCUSSION}

PA production

The dry distillation of $\mathrm{G}$. angustifolia preserved $(372.5 \mathrm{~kg})$ produced $81 \mathrm{~kg}$ of charcoal at a percentage yield $22 \%, 59 \mathrm{~kg}$ of non-carbonized bamboo at a percentage yield $16 \%, 15 \mathrm{~kg}$ of ashes at a percentage yield $4.10 \%$ and $1850 \mathrm{~mL}$ of PAC were obtained corresponding to $0.50 \%$ of the initial raw material. The dry distillation of G. angustifolia non-preserved (153 kg) produced $30 \mathrm{~kg}$ of charcoal at a percentage yield $20 \%$, $20.2 \mathrm{~kg}$ of non-carbonized bamboo at a percentage yield $13 \%, 6.4 \mathrm{~kg}$ of ashes at a percentage yield $4.18 \%$ and $600 \mathrm{~mL}$ of PAC were obtained corresponding to $0.39 \%$ of the initial raw material.

Chemical composition of PA extracts

Solvent extraction is the technique most frequently employed for the isolation of antioxidants, and both the extraction yield and the activity of the extracts depend strongly on the solvent used because the antioxidant potential depends on polarity [23]. Therefore, the liquid-liquid extraction was carried out using hexane, which, according to the literature, is a slightly polar compound that exhibits no dipole moment.

The compounds were identified according to their retention times, comparing their mass with those from the NIST Mass Spectral commercial library. The normalization method of peak area was applied to determine the relative content of compounds in PA [24]. A total of 66 compounds with approximate match percentage $\geq 89 \%$ were identified, divided into the following groups: phenolic compounds, ketones, furan and pyran derivatives, alkyl aryl ether and organic acid. In addition, there were small number of esters, alcohols, amides, and aldehydes. The main organic compounds in PAC and PAS were phenols and derivates, accounting for $62.62 \%$ and $55.29 \%$, respectively. The chemical composition of the PA samples is shown in Table 1.

Phenolic compounds such as phenol, guaiacol, syringol, pyrocatechol and their derivatives are the result of the thermal decomposition of lignin [25]. On the other hand, saccharides, including cellulose, hemicellulose, and pectin, are thermally degraded into ketones, alcohols, furan and pyran derivatives [26].

Table 1. Chemical compounds identified in the PA samples.

\section{PAC PAS}

\begin{tabular}{|c|c|c|c|c|c|c|c|c|}
\hline $\mathbf{N}^{\circ}$ & $\begin{array}{c}\text { Retentio } \\
\text { n Time } \\
\text { (min) }\end{array}$ & Compound & $\begin{array}{l}\text { Molecular } \\
\text { Formula }\end{array}$ & $\begin{array}{c}\text { Molar } \\
\text { Mass } \\
\left(\mathrm{g} \mathrm{mol}^{-1}\right)\end{array}$ & $\begin{array}{c}\text { Similarity } \\
(\%)\end{array}$ & $\begin{array}{l}\text { Area } \\
(\%)\end{array}$ & $\begin{array}{l}\text { Similari } \\
\text { ty (\%) }\end{array}$ & $\begin{array}{c}\text { Area } \\
(\%)\end{array}$ \\
\hline & & $\begin{array}{c}\text { Furan and pyran } \\
\text { derivatives }\end{array}$ & & & & 5.99 & & 3.3 \\
\hline 1 & 2.57 & $\begin{array}{c}2,5- \\
\text { Dimethyltetrahydrofuran }\end{array}$ & $\mathrm{C}_{6} \mathrm{H}_{12} \mathrm{O}$ & 100.16 & 94 & 0.12 & -- & $\mathrm{nq}$ \\
\hline 2 & 2.98 & 2-Methoxytetrahydrofuran & $\mathrm{C}_{5} \mathrm{H}_{10} \mathrm{O}_{2}$ & 101.13 & 96 & 0.85 & 97 & 0.47 \\
\hline 3 & 4.61 & 2-Furanmethanol & $\mathrm{C}_{5} \mathrm{H}_{6} \mathrm{O}_{2}$ & 98.09 & -- & $\mathrm{nq}$ & 94 & 0.19 \\
\hline 4 & 5.96 & 1-(2-Furanyl)- ethanone & $\mathrm{C}_{6} \mathrm{H}_{6} \mathrm{O}_{2}$ & 110.11 & 94 & 1.71 & 90 & 0.91 \\
\hline 5 & 7.72 & Methyl 2-furoate & $\mathrm{C}_{6} \mathrm{H}_{6} \mathrm{O}_{3}$ & 126.11 & 89 & 0.38 & 92 & 0.34 \\
\hline 6 & 8.60 & $\begin{array}{l}\text { Tetrahydro-2- } \\
\text { furanmethanol }\end{array}$ & $\mathrm{C}_{5} \mathrm{H}_{10} \mathrm{O}_{2}$ & 102.13 & 89 & 0.19 & 93 & 0.57 \\
\hline 7 & 8.70 & $\begin{array}{l}\text { 1-(2-Furanyl)-1- } \\
\text { propanone }\end{array}$ & $\mathrm{C}_{7} \mathrm{H}_{8} \mathrm{O}_{2}$ & 124.13 & 95 & 0.29 & 94 & 0.16 \\
\hline & & Organic acid & & & & 2.45 & & 0.66 \\
\hline 8 & 2.83 & 2-Methylpropanoic acid & $\mathrm{C}_{4} \mathrm{H}_{8} \mathrm{O}_{2}$ & 88.11 & 95 & 0.43 & 94 & 0.08 \\
\hline 9 & 3.25 & Butanoic acid & $\mathrm{C}_{4} \mathrm{H}_{8} \mathrm{O}_{2}$ & 88.11 & 98 & 1.38 & 96 & 0.45 \\
\hline
\end{tabular}


Cont. Table 1

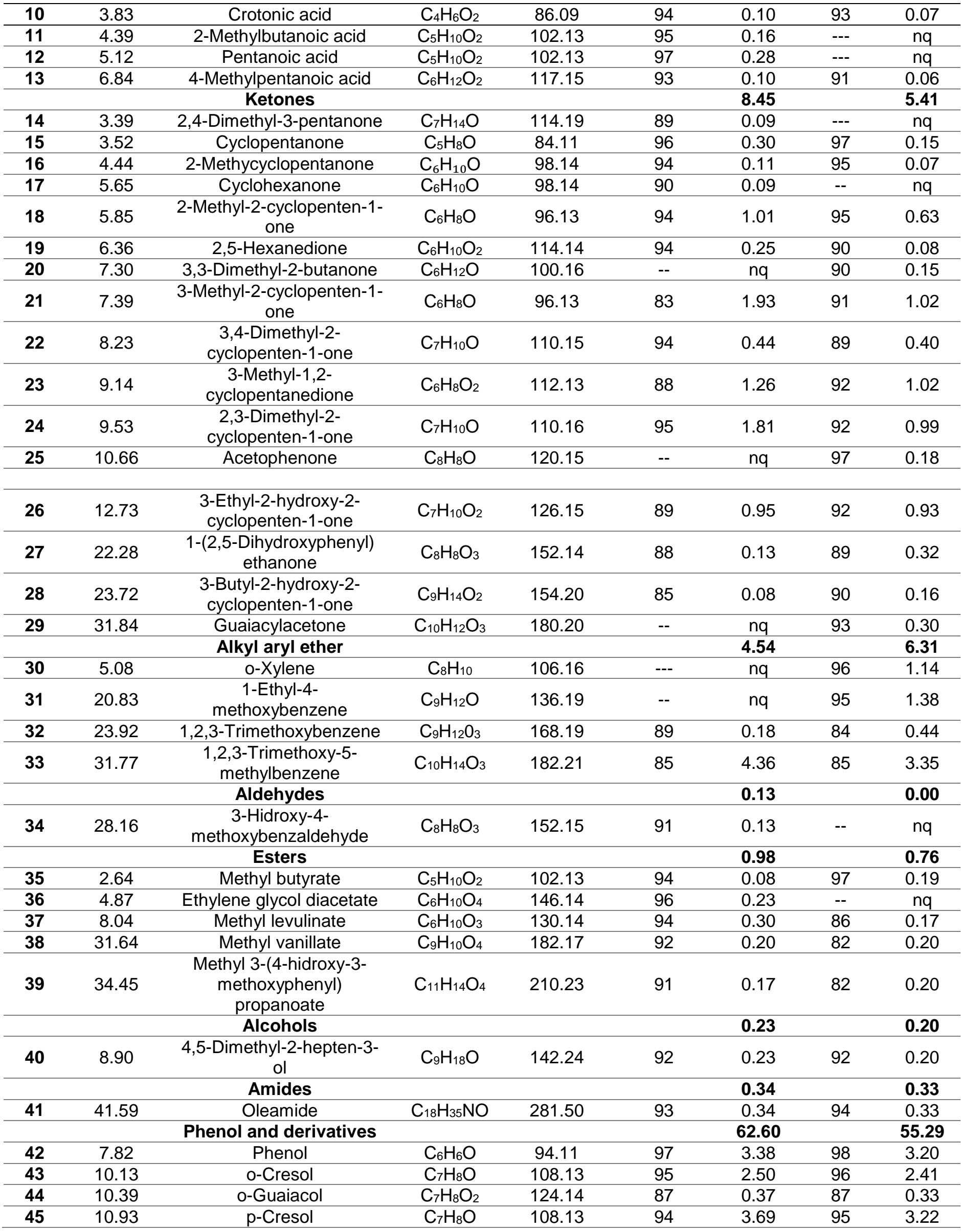


Cont. Table 1

\begin{tabular}{|c|c|c|c|c|c|c|c|c|}
\hline 46 & 11.47 & Mequinol & $\mathrm{C}_{7} \mathrm{H}_{8} \mathrm{O}_{2}$ & 124.14 & 98 & 15.83 & 97 & 9.87 \\
\hline 47 & 12.39 & 2,6-Dimethylphenol & $\mathrm{C}_{8} \mathrm{H}_{10} \mathrm{O}$ & 122.16 & 82 & 0.27 & 96 & 0.66 \\
\hline 48 & 13.73 & $\begin{array}{l}\text { 2-Methoxy-3- } \\
\text { methylphenol }\end{array}$ & $\mathrm{C}_{8} \mathrm{H}_{10} \mathrm{O}_{2}$ & 138.16 & 86 & 0.03 & -- & $\mathrm{nq}$ \\
\hline 49 & 13.87 & 2-Ethylphenol & $\underline{\mathrm{C}_{8} \mathrm{H}_{10} \mathrm{O}}$ & 122.16 & 76 & 0.53 & 89 & 0.87 \\
\hline 50 & 14.56 & 2,4-Dimethylphenol & $\mathrm{C}_{8} \mathrm{H}_{10} \mathrm{O}$ & 122.16 & 96 & 0.83 & 96 & 1.48 \\
\hline 51 & 15.71 & 4-Ethylphenol & $\mathrm{C}_{8} \mathrm{H}_{10} \mathrm{O}$ & 122.16 & 98 & 7.14 & 98 & 6.33 \\
\hline 52 & 15.85 & 3-Ethylphenol & $\mathrm{C}_{8} \mathrm{H}_{10} \mathrm{O}$ & 122.16 & 79 & 0.01 & 86 & 0.39 \\
\hline 53 & 17.44 & Isocreosol & $\mathrm{C}_{8} \mathrm{H}_{10} \mathrm{O}_{2}$ & 138.17 & 97 & 9.47 & 96 & 6.81 \\
\hline 54 & 17.69 & 3,5-Dimethylphenol & $\mathrm{C}_{8} \mathrm{H}_{10} \mathrm{O}$ & 122.16 & 92 & 0.08 & 92 & 0.55 \\
\hline 55 & 20.26 & p-Cumenol & $\mathrm{C}_{9} \mathrm{H}_{12} \mathrm{O}$ & 136.19 & 91 & 0.22 & -- & $\mathrm{nq}$ \\
\hline 56 & 20.83 & 2-Ethyl-4-methylphenol & $\mathrm{C}_{9} \mathrm{H}_{12} \mathrm{O}$ & 136.19 & 93 & 0.48 & 90 & 0.13 \\
\hline 57 & 22.13 & 2,3,5-Trimethylphenol & $\mathrm{C}_{9} \mathrm{H}_{12} \mathrm{O}$ & 136.19 & 86 & 0.12 & 91 & 0.22 \\
\hline 58 & 22.41 & 4-Ethyl-2-methoxyphenol & $\mathrm{C}_{9} \mathrm{H}_{12} \mathrm{O}_{2}$ & 152.19 & 93 & 5.04 & 94 & 8.75 \\
\hline 59 & 25.72 & 2,6-Dimethoxyphenol & $\mathrm{C}_{8} \mathrm{H}_{10} \mathrm{O}_{3}$ & 154.17 & 94 & 7.48 & 94 & 5.09 \\
\hline 60 & 26.06 & Eugenol & $\mathrm{C}_{10} \mathrm{H}_{12} \mathrm{O}_{2}$ & 164.20 & 95 & 0.24 & 95 & 0.67 \\
\hline 61 & 26.62 & 2-Methoxy-4-propylphenol & $\mathrm{C}_{10} \mathrm{H}_{14} \mathrm{O}_{2}$ & 166.22 & 89 & 0.12 & 92 & 0.81 \\
\hline 62 & 29.85 & $\begin{array}{l}\text { 3,5-Dimethoxy-4- } \\
\text { hydroxytoluene }\end{array}$ & $\mathrm{C}_{9} \mathrm{H}_{12} \mathrm{O}_{3}$ & 168.18 & 92 & 3.94 & 92 & 2.25 \\
\hline 63 & 30.02 & trans-Isoeugenol & $\mathrm{C}_{10} \mathrm{H}_{12} \mathrm{O}_{2}$ & 164.20 & -- & $\mathrm{nq}$ & 92 & 0.36 \\
\hline 64 & 30.89 & $\begin{array}{c}\text { 1-(4-Hidroxy-3- } \\
\text { methoxyphenyl) ethanone }\end{array}$ & $\mathrm{C}_{9} \mathrm{H}_{10} \mathrm{O}_{3}$ & 166.17 & 93 & 0.13 & -- & $\mathrm{nq}$ \\
\hline 65 & 32.22 & $\begin{array}{l}\text { 2,6-Dimethoxy-4-(2- } \\
\text { propenyl) phenol }\end{array}$ & $\mathrm{C}_{11} \mathrm{H}_{14} \mathrm{O}_{3}$ & 194.23 & 94 & 0.62 & 93 & 0.73 \\
\hline 66 & 34.31 & $\begin{array}{l}\text { (E)-2,6-Dimethoxy-4- } \\
\text { (prop-1-en-1-yl) phenol }\end{array}$ & $\mathrm{C}_{11} \mathrm{H}_{14} \mathrm{O}_{3}$ & 194.22 & 83 & 0.08 & 84 & 0.16 \\
\hline & & Total & & & & 84.73 & & 72.26 \\
\hline
\end{tabular}

${ }^{*}$ nq: not quantified.

As shown in Table 1, compounds identified from the two PA samples are typical pyrolytic products since they are obtained from decomposition of the organic matter of Guadua, which is mainly composed of lignin. This natural phenolic polymer confers rigidity to the cell wall of wooden plants and, in conjunction with cellulose, is responsible for the mechanical support of stems, branches and leaves. Native lignin usually contains eleven (11) monomer fragments. The basic molecular conformation of lignin is a three-dimensional polymer of the 4-hydroxy-4-methoxy-phenyl-propane group that reaches high molar mass (5000-10000 g mol-1) [27].

The major substances in the PAC sample were mequinol (15.83\%), isocreosol $(9.47 \%), 2,6$ dimethoxyphenol (7.48\%), 4-ethylphenol (7.14\%) and 4-ethyl-2-methoxyphenol (5.04\%); the chromatogram of the PA sample is shown in Figure 2. The major substances in the PAS sample were mequinol $(9.87 \%)$, 4ethyl-2-methoxyphenol (8.75\%), isocreosol (6.81\%), 4-ethylphenol (6.33\%), and 2,6-dimethoxyphenol $(5.09 \%)$; the chromatogram of this sample is shown in Figure 3 . The relative content of mequinol (4methoxyphenol) was significant in the two acid samples. This compound is used as a topical solution for skin reconstruction when there are hyperpigmentation problems. It is approved as an active ingredient with therapeutic equivalence evaluations by the FDA, in addition to being registered in the EU Food Improvement Agents database as a Flavoring Agent. 


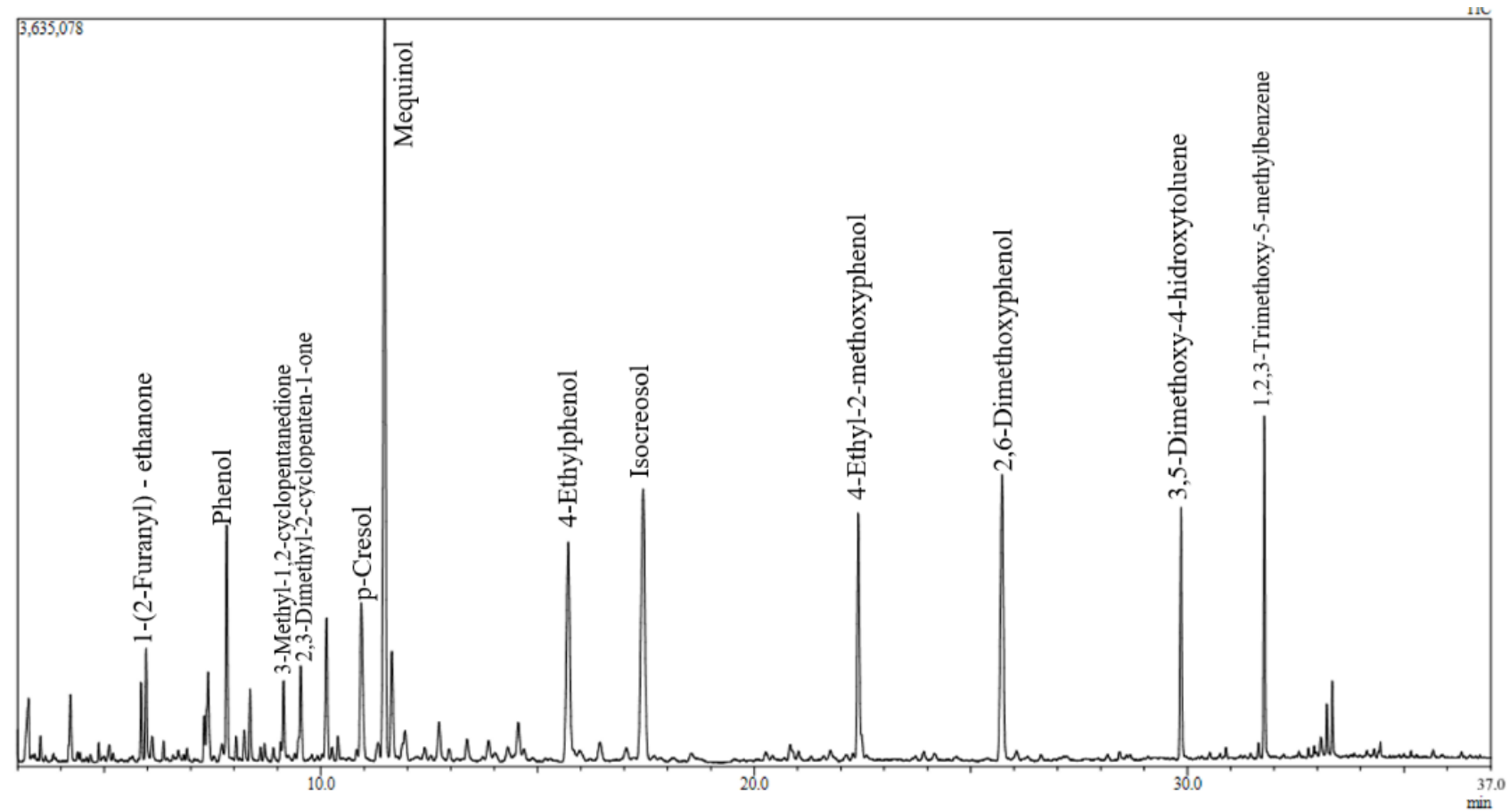

Figure 2. Chromatographic profile of pyroligneous acid pretreated with borax (PAC).

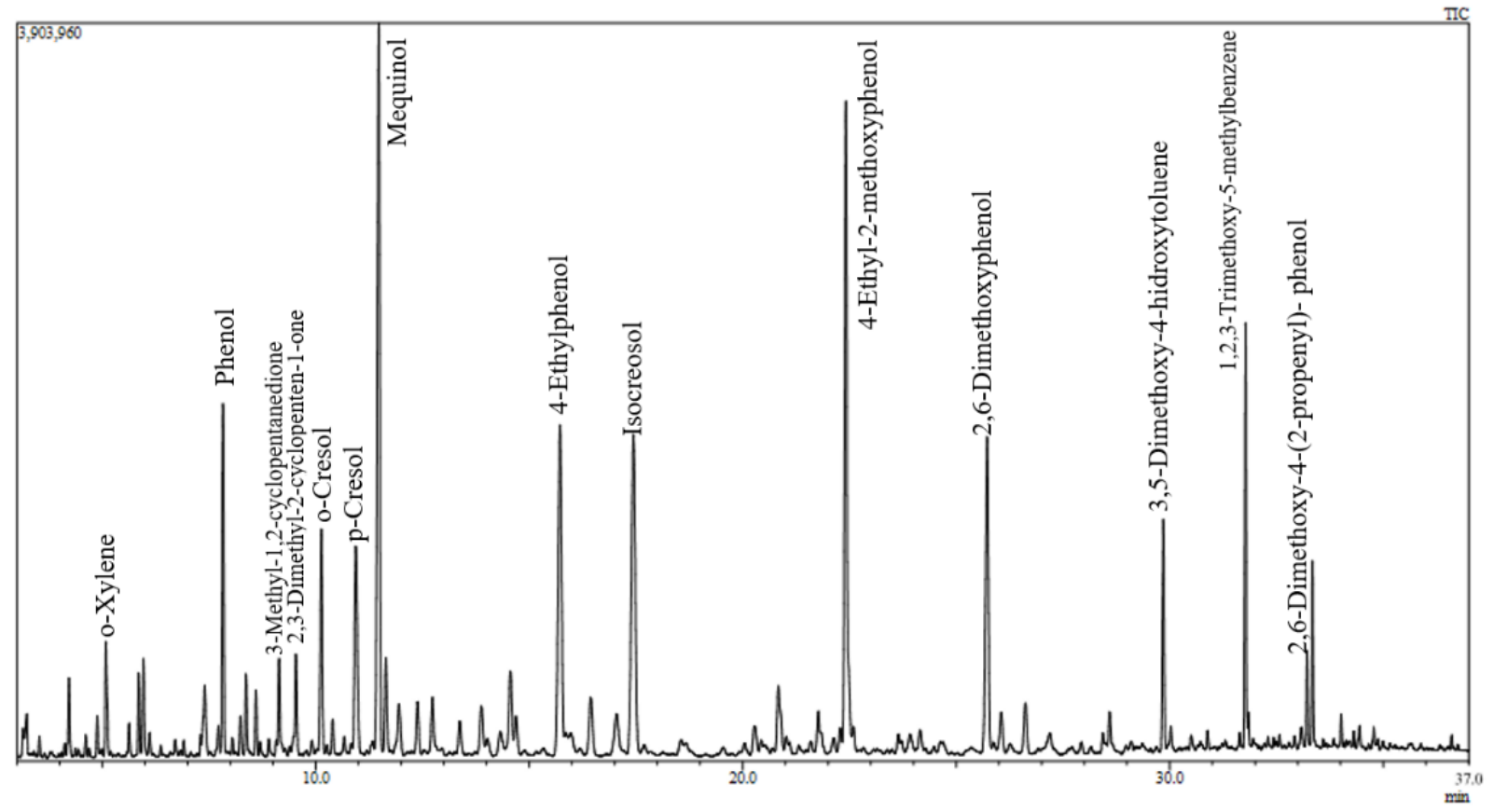

Figure 3. Chromatographic profile of pyroligneous acid not treated with borax (PAS). 

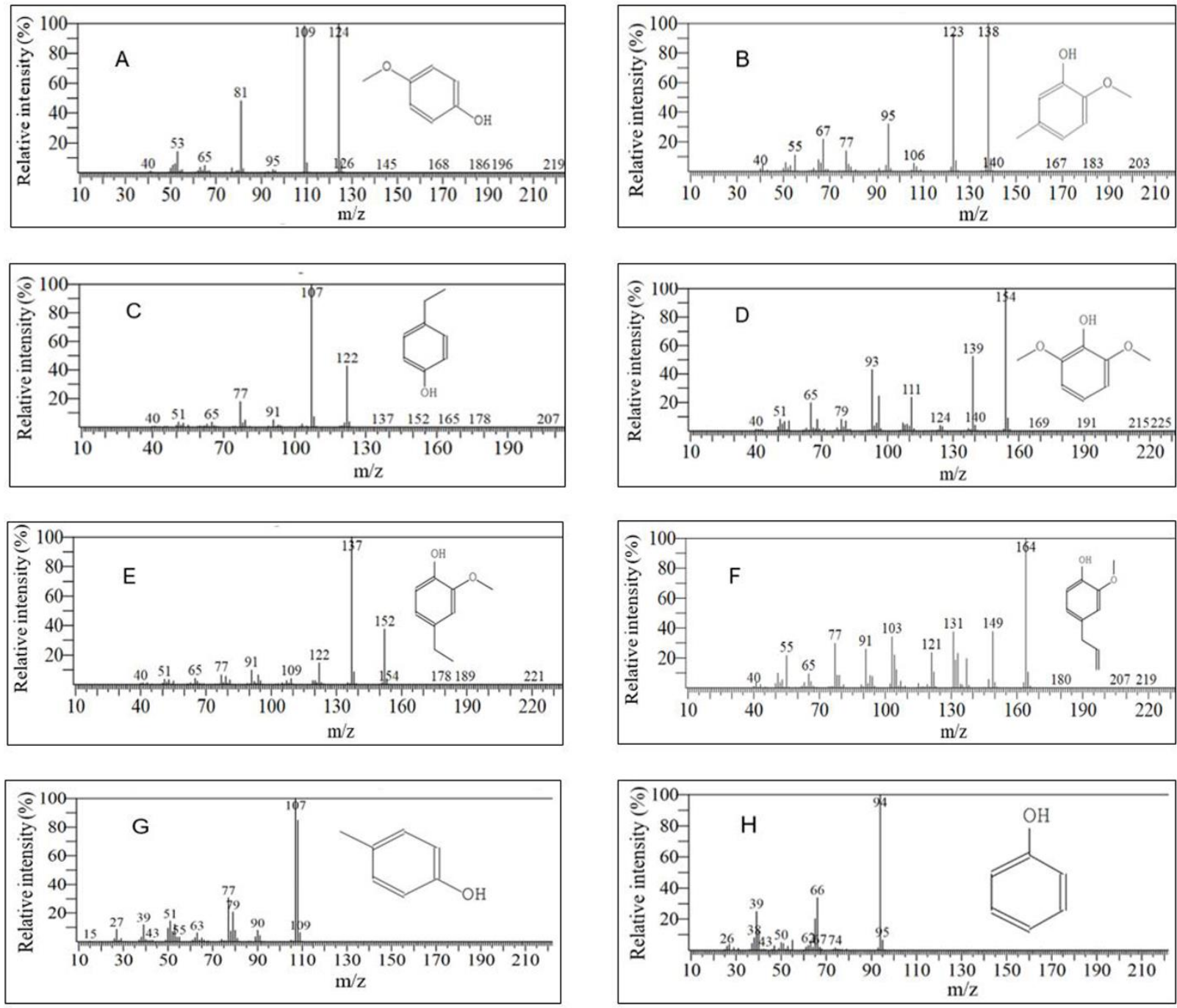

Figure 4. Mass spectra of the main constituents of the PA samples: mequinol $[A]$, isocreosol $[B]$, 4-ethylphenol $[C], 2,6$ dimethoxyphenol [D], 4-ethyl-2-methoxyphenol [E], eugenol [F], p-cresol [G] and phenol $[\mathrm{H}]$.

4-Ethyl-2-methoxyphenol is known for its smoky odor, and it is commonly used as the main compound in liquid flavorings. 1,2,3-Trimethoxy-5-methylbenzene $(4.36 \%$ and $3.35 \%)$ is a volatile compound, with an average retention time of $31.77 \mathrm{~min}$, found mainly in dark teas [28,29,30]. o-Guaiacol (2-methoxyphenol) has a role as expectorant, disinfectant, plant metabolite and flavor agent. 1-(2-Furanyl)- ethenone, butanoic acid, 3-methyl-2-cyclopenten-1-one, methyl vanillate, 4-ethylphenol, 2, 6-dimethylphenol, isocreosol (2-methoxy5-methylphenol) and oleamide are used in flavor compositions; includes spices (condiments and seasonings), extracts, colorings, flavors, etc., added to food for human consumption. These compounds are found as flavoring agents in the EU food improvement agents and FAO/WHO Food additive evaluations (JECFA).

According to previous studies, the percentage of lignin present in $G$. angustifolia grown in the above mentioned Colombian ecoregion can vary between $20.0 \%$ and $38.15 \%$ [31]. For this reason, the major components of the PAs studied are phenols and their derivatives (Figure 4). Pentanoic acid (0.28\%), ethylene glycol diacetate $(0.23 \%)$ and p-cumenol $(0.22 \%)$ were identified only in the PAC sample. 1-Ethyl-4methoxybenzene $(1.38 \%)$, o-xylene $(1.14 \%)$ and trans-isoeugenol $(0.36 \%)$ were only identified in PAS sample. The reason for this minor different in chemical composition of PA is that depends on whether the pyrolysis is slow or rapid and on the variation in temperature and composition of the biomass.

Compared to other acids, in the PA from Guadua sarcocarpa the major phenolic compounds were Guaiacol (5.13\%) and 2,6-dimethoxyphenol (7.18\%). Moreover, mequinol was not identified in the PA of Guadua sarcocarpa [14]. In the PA from pineapple plant waste the major phenolic compound as 2,6dimethoxyphenol (32.90\%), followed by phenol (14.80\%) and 1,2-benzenediol (7.90\%) [13]. In the PA from softwood mixture had compounds such as catechol (8.72\%), 4-methylcatechol $(7.41 \%)$ and acetic acid $(3.90 \%)$ which are characteristic of the biomass used [32]. However, in the case of PA from G. angustifolia, 
these types of compounds were not detected. Gallón and coauthors [33] reported a profile of volatile compounds of $G$. angustifolia from Caicedonia Valle del Cauca, as presented in this investigation; where the most important components were p-guaiacol (7.50\%), phenol (15.45\%), and syringol (17.76). Panita and others [34] found significant amounts of acetic acid (62.10\%), phenol (4.23\%) and 1-hydroxy-2-propane $(5.30 \%)$ in the PA from the bamboo species Dendrocalamus asper Backer, they determine its effect as an anticoagulant agent for the production of natural rubber sheets.

This research confirms the fact that the volatile compounds of the PA samples of G. angustifolia have a similar composition to that reported by other researchers, as shown above. The results therefore indicate the high development potential starting from these different products with applications in medicine, agriculture, and in the food industry, and many researchers have conducted studies on the chemical characterization of PA obtained from different species of bamboo around the world.

The total phenolic content (TPC) by the Folin-Ciocalteu assay

TPC is an important indicator of antioxidant activity and is measured for products intended to be used as sources of natural antioxidants in functional foods [13]. It is a simple and reliable method used in determining the phenolic content of samples. The TPC of the extracts was expressed as gallic acid equivalents (mg GA g-1 of sample) as shown in Table 2. The samples have varying concentrations of phenolic activity, with phenolic activity in PAS at $(3.84 \pm 0.03 \mathrm{mg} \mathrm{GA} \mathrm{g}-1)$ and in PAC at (1.96 $\pm 0.01 \mathrm{mg} \mathrm{GA} \mathrm{g-1)}$. The difference in the results was attributed to the different pyrolysis process and the different chemical composition of the extracts, although the phenolic content in the two samples did not vary much because the same raw material, was used.

The phenolic content in PA from G. angustifolia can not be compared with other research of bamboo, as no literature support of this assay was found for this type of material. However, considering other plants, the TPC of the PA from $G$. angustifolia is relatively higher than those from pineapple (2.67 $\pm 0.14 \mathrm{mg} \mathrm{GA} \mathrm{g-1)} \mathrm{[13]}$ and the leaves of Rosmarinus officinalis $(3.43 \pm 0.10 \mathrm{mg} \mathrm{GA} \mathrm{g-1)}$ [22]. The reason for this is probably that bamboo has a higher lignin content than these other plants.

DPPH free radical scavenging activity

The free radical 2,2-diphenyl-1-picrylhydrazyl is one of the few organic radicals containing nitrogen that is reduced in the presence of hydrogen-donating antioxidants, leading to the formation of DPPH-H (diphenyl hydrazine) [13] which is not a radical, due to the ability of the DPPH radical to form bonds with hydrogen atoms. Discoloration occurs due to the decreasing concentration of DPPH radicals in the solution [35]. Therefore, the discoloration of the DPPH is an indication of the radical scavenging activity of the PA samples analyzed.

In this test, the color changes from purple to yellow after reduction, which is quantified by the decrease in absorbance over time. The percentage of inhibition determined is an indication of the antioxidant capacity of the PA samples evaluated. To carry out the DPPH assay, the concentrated extracts were diluted to a final concentration of $1 \% /(\mathrm{w} / \mathrm{v})$ in each of the samples. PAS show lower radical scavenging activity that PAC probably because its phenolic composition is a slight lower that of PAC. PAC and PAS exhibited a DPPH radical scavenging activity, on the order of $70.98 \pm 0.92 \%$ and $16.67 \pm 0.30 \%$, respectively. These results are considered significant compared to results of other researchers such as Wei Qin and coauthors studied the antioxidant activity of PA samples obtained from walnut shells and obtained free radical elimination percentages of $65.61 \%, 73.96 \%$ and $85.62 \%$ for concentrations of $5 \mathrm{mg} \mathrm{mL}^{-1} \mathrm{PA}$ [12]; the higher the concentrations, the higher the percentage of inhibition. Other example was Loo A.Y. and coauthors studied the antioxidant activity of the mangrove shrub Rhizophora apiculata and found percentages of inhibition of $43.42 \%$ and $80.96 \%$ [10]. These results are promising given that in recent years, the search for natural antioxidants to replace synthetic antioxidants for use in food and in medicine has been intensified. Certain synthetic antioxidants, such as butylated hydroxyanisole (BHA), butylated hydroxytoluene (BHT), and tertiary butyl hydroxyquinone (TBHQ), are restricted due to their side effects (e.g., carcinogenicity) [36]. Currently, attention has been directed towards the discovery and use of natural antioxidants obtained from plants such as $G$. angustifolia, which grows extensively in the center of the western region of Colombia, S.A. 
Table 2. Antioxidant activity of PA extracts.

\begin{tabular}{|c|c|c|c|c|}
\hline \multirow{3}{*}{ Extracts } & \multicolumn{4}{|c|}{ Antioxidant activity } \\
\hline & \multicolumn{2}{|c|}{ TPC assay } & \multicolumn{2}{|c|}{ DPPH assay } \\
\hline & Absorbance & $\begin{array}{l}\text { Gallic acid equivalents } \\
\left.\text { (mg GAE } \mathrm{g}^{-1}\right)\end{array}$ & Absorbance & $\begin{array}{l}\text { Free radical scavenging activity } \\
(\%)\end{array}$ \\
\hline $\begin{array}{l}\text { PAC } \\
\text { PAS }\end{array}$ & $\begin{array}{l}0.429 \pm 0.002 \\
0.525 \pm 0.003\end{array}$ & $\begin{array}{l}1.96 \pm 0.01 \\
3.84 \pm 0.03\end{array}$ & $\begin{array}{l}0.162 \pm 0.005 \\
0.427 \pm 0.002\end{array}$ & $\begin{array}{l}70.98 \pm 0.92 \\
16.67 \pm 0.30\end{array}$ \\
\hline
\end{tabular}

\section{CONCLUSION}

As determined by GC-MS, phenolic compounds, organic acids, and ketones are prevalent in the chemical composition of the PA samples. Compounds such as 4-ethyl-phenol, mequinol (4-methoxyphenol), isocreosol (2-methoxy-5-methylphenol), 4-ethyl-2-methoxyphenol, and 1,2,3-trimethoxy-5-methylbenzene deserve mention. 2,6-Dimethoxyphenol compounds are used in the pharmaceutical industry (as depigmenting agents) and in the food industry (as additives). Other compounds found were phenol, p-cresol, $\mathrm{m}$-cresol, o-cresol, and 4-ethylphenol, and other number of compounds. The phenolic compounds that, due to their structure, are responsible for the reduction of oxidants and elimination of the free radical DPPH gives this acid a high antioxidant character. The compounds found in this study have potential uses in pesticides as an antimicrobial agent to control plant diseases and as a fungicidal agent, and food industries as well as in medicine. The difference between the two PA samples (PAC and PAS) in terms of their composition is not very remarkable; both have the same compounds and in similar proportions. This observation shows that when obtaining the acid, it does not matter whether the $G$. angustifolia is subjected to a treatment with borax or not, obtaining a high PA yield regardless.

Recommendations

It is important to perform monitoring of the commercial and technological environment, focusing on the possible applications of PA in research, as well as in the food, agrochemical, and pharmaceutical industries as an expectorant and local anesthetic. Due to its phenol-rich composition it has some therapeutic value as a fungicide, antiseptic and disinfectant, with activity against a wide range of microorganisms including some viruses, or as a raw material for other industries. In this way, new economic opportunities are created for rural communities, taking advantage of this subproduct obtained during charcoal production from $G$. angustifolia grown in the Colombian central western region. It is also recommended to perform complementary studies to verify the effectiveness of PA treatment against specific pests. In addition, it is necessary to perform a toxicity analysis on the effects of this acid on human beings. Such analysis is key to verifying the safety of PA as a material intended for use in the food, agriculture, and medicine markets.

Funding: Vice-Rectory of Research of Technological University of Pereira, Internal Call to Finance the Publication of Scientific Research Articles year 2019.

Acknowledgments: The authors thank to the Oleochemical Research Group, the Cleaner Production Research Group, the firm Guaduasecol SAS, to the students Daniela Hurtado and Camila Contreras, to Luis Guillermo Rios for his support in the editing process and to the Universidad Tecnológica de Pereira allowing the development of this project.

Conflicts of Interest: The authors do not have any conflict of interest.

\section{REFERENCES}

1. Yebra Gónzalez O. (Characterization of Guadua bamboo (Guadua angustifolia) for design and industrialization in Spain). 94th ed. Editorial Universidad de Almería; 2014. Spanish.

2. Fryda L, Daza C, Pels J, Janssen A, Zwart R. Lab-scale co-firing of virgin and torrefied bamboo species Guadua angustifolia Kunth as a fuel substitute in coal fired power plants. Biomass Bioenerg. 2014;65:28-41.

3. Morales Hidalgo D, Kleinn C. An inventory of Guadua (Guadua angustifolia) bamboo in the Coffee Region of Colombia. Eur J For Res. 2006;125:361-8.

4. Camargo JC, Arango AM, Maya JM, Bueno L. (Guadua angustifolia in the Colombian coffee ecoregion). 2018. p. 56-61. Spanish.

5. Mosquera Martínez OM, González Cadavid LM, Cortés Ossa YJ, Camargo García JC. (Phytochemical characterization of acetone extracts and lignin content in Guadua angustifolia culms). Recur Nat y Ambient. 2012;65(66):10-5. Spanish.

6. Castells XE, Velo García E. (Pyrolysis: Treatment and energy valuation of waste). Ediciones Díaz de Santos; 2012. Spanish.

7. Souza JBG, Ré-Poppi N, Raposo JL. Characterization of pyroligneous acid used in agriculture by gas chromatography-mass spectrometry. J Braz Chem Soc. 2012;23(4):610-7.

8. Wei Q, Ma X, Dong J. Preparation, chemical constituents and antimicrobial activity of pyroligneous acids from 
walnut tree branches. J Anal Appl Pyrolysis. 2010;87(1):24-8.

9. Li R, Narita R, Nishimura H, Marumoto S, Yamamoto SP, Ouda R, et al. Antiviral Activity of Phenolic Derivatives in Pyroligneous Acid from Hardwood, Softwood, and Bamboo. ACS Sustain Chem Eng. 2017;6(1):119-26.

10. Loo AY, Jain K, Darah I. Antioxidant and radical scavenging activities of the pyroligneous acid from a mangrove plant, Rhizophora apiculata. Food Chem. 2007;104(1):300-7.

11. Rabiu Z, Nisa K, Hasham R, Akmar Z. Characterization and antioxidant properties of ethyl acetate fractions from pyroligneous acid obtained by slow pyrolysis of palm kernel. 2019;15(5):644-50.

12. Wei Q, Ma X, Zhao Z, Zhang S, Liu S. Antioxidant activities and chemical profiles of pyroligneous acids from walnut shell. J Anal Appl Pyrolysis. 2010;88(2):149-54.

13. Mathew S, Zakaria ZA, Musa NF. Antioxidant property and chemical profile of pyroligneous acid from pineapple plant waste biomass. Process Biochem. 2015;50(11):1985-92.

14. Catacora P M, Quispe A I, Julian L E, Zanabria M R, Roque C M, Zevallos P P. (Characterization of the chemical components of pyroligneous acid obtained from 3 forest species, for agricultural purposes in San Gaban, Puno (Peru)). El Ceprosimad. 2019;07(2):6-16. Spanish.

15. Burbano S D. (Use of Kikuyo (Pennisetum Clandestium L), residue from the pruning of green areas to obtain pyroligneous acid for agricultural purposes). Rev del Inst Investig la Fac Ing Geológica, Minera, Met y Geográfica. 2018;21(41):3-8. Spanish.

16. Ocampo G CM. (Pyroligneous acid compounds from residual biomass of cypress (Cupressus lusitanica Mill) and patula (Pinus patula) conifers). Rev Univ Católica Oriente. 2015;28(40):94-104. Spanish.

17. Prías B JJ, Rojas González CA, Echeverry Montaya NA, Fonthal G, Ariza Calderón H. (Identification of the optimal variables for obtaining activated carbon from the precursor Guadua angustifolia Kunth). Vol. 35, Revista Acad. Colomb. Ci. Exact. 2011; 157-66. Spanish.

18. Montoya Arango JA. (Technological research in methods for the preservation of Guadua). Memorias Semin Av en la Investig sobre Guadua. 2002;44(2):16. Spanish.

19. Burgos F A, Montoya Arango JA. (Effect of concentration, temperature and immersion time on retention and penetration of boron in Guadua angustifolia Kunth). Rev Agric Andin. 2015;21:15-26. Spanish.

20. Pimenta AS, Fasciotti M, Monteiro TVC, Lima KMG. Chemical composition of pyroligneous acid obtained from Eucalyptus GG100 Clone. Molecules. 2018;23(426):1-12.

21. Brand Williams W, Cuvelier ME, Berset C. Use of a free radical method to evaluate antioxidant activity. LWT - Food Sci Technol. 1995;28(1):25-30.

22. Ma C, Song K, Yu J, Yang L, Zhao C, Wang W, et al. Pyrolysis process and antioxidant activity of pyroligneous acid from Rosmarinus officinalis leaves. J Anal Appl Pyrolysis. 2013;104:38-47.

23. Loo AY, Jain K, Darah I. Antioxidant activity of compounds isolated from the pyroligneous acid, Rhizophora apiculata. Food Chem. 2008;107(3):1151-60.

24. Zhai M, Shi G, Wang Y, Mao G, Wang D, Wang Z. Chemical compositions and biological activities of pyroligneous acids from Walnut Shell. BioResources. 2015;10(1):1715-29.

25. Wenzl HFJ. The chemical technology of wood. London: Academic Press INC; 1970.

26. Siddhuraju P. Antioxidant activity of polyphenolic compounds extracted from defatted raw and dry heated Tamarindus indica seed coat. LWT - Food Sci Technol. 2007;40(6):982-90.

27. Castaño Nieto F. (Technical definition of a regime for the use of bamboo forests (Guadua angustifolia Kunth) and its impact on the sustainability, health and profitability of the resource Experiences in the province of Valle del Cauca, Colombia and the province of Guayaquil, Ecuador). Cali, Colombia: Corporación Autónoma Regional del Valle del Cauca (CVC); Agencia Internacional para el Desarrollo (AID-FORDE); 2001. Spanish.

28. Lau H, Liu SQ, Xu YQ, Tan LP, Zhang WL, Lassabliere B, et al. Characterizing volatiles in tea (Camellia sinensis). Part II: Untargeted and targeted approaches to multivariate analysis. LWT. 2018;94:142-62.

29. Lv H, Zhang Y, Shi J, Lin Z. Phytochemical profiles and antioxidant activities of Chinese dark teas obtained by different processing technologies. Food Res Int. 2017;100:486-93.

30. Lv H-P, Zhong Q-S, Lin Z, Wang L, Tan J-F, Guo L. Aroma characterization of Pu-erh tea using headspace-solid phase microextraction combined with GC/MS and GC-olfactometry. Food Chem. 2012;130(4):1074-81.

31. Marino Mosquera O, Cortes YJ, Osorio JN. (Guadua angustifolia in the Colombian coffee ecoregion). Recur Nat y Ambient. 2010;(61):11-7. Spanish.

32. Suresh G, Pakdel H, Rouissi T, Brar SK, Fliss I, Roy C. In vitro evaluation of antimicrobial efficacy of pyroligneous acid from softwood mixture. Biotechnol Res Innov. 2019; 3, 47-53.

33. Mejía Gallón Al, Ramírez López G, Palacio Torres HD, López C. Identification of volatile compounds in vinegar from Guadua angustifolia Kunth. (guadua). Rev Cuba Plantas Med. 2011;16(2):190-201. 
34. Sumanatrakul P, Kongsune P, Chotitham L, Sukto U. Utilization of Dendrocalamus Asper Backer Bamboo Charcoal and Pyroligneous Acid. Energy Procedia. 2015;79:691-6.

35. Aksoy L, Kolay E, Ağılönü Y, Aslan Z, Kargıoğlu M. Saudi. Free radical scavenging activity, total phenolic content, total antioxidant status, and total oxidant status of endemic Thermopsis turcica. J Biol Sci. 2013;20(3):235-9.

36. Valentão P, Fernandes E, Carvalho F, Andrade PB, Rosa M. Seabra A, M. Lourdes Bastos. Antioxidative properties of cardoon (Cynara cardunculus L.) infusion against superoxide radical, hydroxyl radical, and hypochlorous acid. J Agric Food Chem. 2002;50(17):4989-93.

2021 by the authors. Submitted for possible open access publication under the terms and conditions of the Creative Commons Attribution (CC BY NC) license (https://creativecommons.org/licenses/by-nc/4.0/). 